\title{
Two new species of the genus Munida Leach, 1820 (Decapoda: Anomura: Munididae) from Indonesia
}

\author{
Ава новых вида рода Munida Leach, 1820 (Decapoda: Anomura: \\ Munididae) из Индонезии
}

\author{
Enrique Macpherson'1, Paula C. Rodríguez-Flores ${ }^{1,2}$, \\ Annie Machordom \\ Энрике Макферсон ${ }^{1}$, Паула К. Родригес-Фцорес ${ }^{1,2}$, \\ Анни Мачордом ${ }^{2}$
}

\footnotetext{
${ }^{1}$ Centre d'Estudis Avançats de Blanes (CEAB-CSIC), C. acc. Cala Sant Francesc, 14, 17300 Blanes, Girona, Spain.

E-mail: macpherson@ceab.csic.es

${ }^{2}$ Museo Nacional de Ciencias Naturales (MNCN-CSIC), José Gutiérrez Abascal, 2, 28006 Madrid, Spain.

E-mail: paularodriguezflores@gmail.comn
}

KEY WORDS: Galatheoidea, integrative taxonomy, West Pacific, mitochondrial genes.

КЛЮЧЕВЫЕ СЛОВА: Galatheoidea, интегративная таксономия, западная часть Тихого океана, митохондриальные гены.

ABSTRACT. Munida vassilyi sp.n. and M. hastata sp.n. are described from Kei Islands, Indonesia. Munida vassilyi sp.n. is morphologically related to M. runcinata, from New Caledonia, Vanuatu, Wallis and Futuna, Fiji and Tonga, whereas M. hastata sp.n. is more similar to $M$. aurantiaca from Papua - New Guinea. Pairwise genetic distances estimated using the COI and 16S rRNA gene fragments indicated high levels of sequence divergence between each new species and their most closely related allies.

How to cite this paper: Macpherson E., RodríguezFlores P.C., Machordom A. 2021. Two new species of the genus Munida Leach, 1820 (Decapoda: Anomura: Munididae) from Indonesia // Arthropoda Selecta. Vol.30. No.3. P.362-368. doi: 10.15298/arthsel. 30.3.09

РЕЗЮМЕ. Munida vassilyi sp.n. и M. hastata sp.n. описаны с островов Кей, Индонезия. Munida vassilyi sp.n морфологически близка к M. runcinata из Новой Каледонии, Вануату, Уоллиса и Футуны, Фиджи и Тонги, в то время как M. hastata sp.n. больше похожа на $M$. aurantiaca из Папуа - Новой Гвинеи. Попарные генетические расстояния, оцененные с использованием фрагментов генных маркеров COI и $16 \mathrm{~S}$ рРНК, показали высокий уровень расхождения последовательностей между новыми и наиболее близкородственными видами.

\section{Introduction}

The genus Munida Leach, 1820 is a very diverse and abundant group of anomuran decapods, containing more than 300 species distributed throughout the world from the coastal area to the abyssal plain [Baba et al., 2008; Schnabel et al., 2011]. This genus has the highest diversity in the western Pacific Ocean, e.g. Coral Sea, Indo-Malay-Philippine Archipelago [Macpherson et al., 2010; Schnabel et al., 2011; Rodríguez-Flores et al., 2019]. Earliest studies by several authors during the last centuries include Henderson [1888] who sampled in the Kei Islands during the HMS Challenger expedition, Ortmann [1894] in Ambon, and De Man [1888, 1902] in Ternate, Moluccas Islands. Since these expeditions, other more recent investigations of Indonesian waters have reported new findings on squat lobsters, including new species of the genus Munida (e.g. Baba [1977, 1988]; Baba, Macpherson [1991]; Macpherson, Baba [1993]; Baba, de Saint Laurent [1996]; Macpherson [1993, 1997]). Furthermore, some authors have studied other genera of squat lobsters, e.g., the galatheoids Leiogalathea, Phylladiorhynchus [Rodríguez-Flores et al., 2019, 2021], or the chirostyloids Eumunida [Gordon, 1930; de Saint-Laurent, Poupin, 1996], Uroptychus [Baba, 2018]. These studies highlight the existence of a rich fauna in Indonesian waters and that a significant portion of the biodiversity probably still remained to be discovered.

During an expedition to Kei Islands, Indonesia, in October 1991 (KARUBAR) [Macpherson, 1997], specimens of two species of squat lobster of the genus Munida Leach, 1820, were collected. The morphological and molecular analyses of these specimens indicate that they have marked morphological and molecular differences from other species of Munida. Therefore, the specimens are described and illustrated here. 


\section{Material and methods}

SAMPLING AND IDENTIFICATION. Specimens were collected using beam trawls. The types are deposited in the collections of the Muséum national d'Histoire naturelle, Paris (MNHN). The general terminology employed in the descriptions largely follows Baba et al. [2009] and Macpherson \& Baba [2011]. The size of the carapace indicates the postorbital carapace length measured along the dorsal midline from the posterior margin of the orbit to the posterior margin of the carapace. The length of each pereopod article is measured in lateral view along its extensor margin (excluding distal spine), the breadth is measured at its widest portion. Abbreviations used are: Mxp3 - maxilliped 3; P1 — pereopod 1; P2-4 - pereopods 2-4; M - male.

MOLECULAR ANALYSIS. Tissue of each specimen was isolated from the muscle of the fifth pereopods and homogenized overnight with $20 \mu \mathrm{l}$ proteinase $\mathrm{K}$ in $180 \mu \mathrm{l}$ of buffer ATL (QIAGEN). The extraction was performed using DNeasy Blood and Tissue Kit following manufacturer instructions (QIAGEN). Two molecular markers were amplified: a fragment from the mitochondrial cytochrome oxidase subunit I (COI) using primers LCO1490 [Folmer et al., 1994] and COI-H [Machordom et al., 2003], and a 16S rRNA (16S) fragment, using 16SAR-16SBR from Palumbi et al. [2002] pair of primers.

The pre-mixing of the PCR reagents was conducted in $25 \mu 1$ total volume, which included $2 \mu 1$ of genomic DNA extract, $0.2 \mathrm{mM}$ of each deoxyribonucleotide triphosphate (dNTP), $0.2 \mu \mathrm{M}$ of each primer forward and reverse, $2 \mathrm{U}$ of MyTaq polymerase (Bioline), $5 \mu$ of $5 \mathrm{x}$ buffer solution with $\mathrm{MgCl}_{2}$ and sterilized $\mathrm{H}_{2} \mathrm{O}$. PCR amplification was performed with a thermal cycle including an initial denaturation at 94 $95^{\circ}$ for $1-4 \mathrm{~min}$ and 40 cycles at $95^{\circ}$ for $1 \mathrm{~min}$, annealing at $42-45^{\circ}$ for $1 \mathrm{~min}$ followed by an extension at $72^{\circ}$ for $1 \mathrm{~min}$. A final extension cycle at $72^{\circ} \mathrm{C}$ was set for $10 \mathrm{~min}$. The amplicons were visualized in agarose $1 \%$ gels and purified using ExoSAP-ITTM PCR Product Cleanup Reagent (Thermo Fischer) before sequencing. The purification products were sent to Secugen S.L. (Madrid) for DNA Sanger sequencing.

The nucleotide sequences of both forward and reverse were visualized and assembled with Sequencher 4.10.1 software package (Gene Codes Corp.). Manual alignment for the COI and 16S genes was carried out in MAFFT [Katoh et al., 2002] and revised in AliView [Larsson, 2014]. Genetic distances between species and their closely related species were estimated using uncorrected divergences ( $p$ ) calculated using PAUP version 4.0 (build 167) [Swofford, 2002]. All the obtained sequences were submitted to GenBank (accession numbers: COI: MZ356538, MZ356539, 16S: MZ357703, MZ357704).

\section{Taxonomy}

Superfamily Galatheoidea Samouelle, 1819 Family Munididae Ahyong, Baba, Macpherson et Poore, 2010

Genus Munida Leach, 1820

\section{Munida hastata sp.n.} Fig. 1.

HOLOTYPE. Indonesia, Kei islands. KARUBAR, Stn DW15, 24/10/1991, $05^{\circ} 17^{\prime} \mathrm{S}, 132^{\circ} 41^{\prime} \mathrm{E}, 212-221 \mathrm{~m}:$ M $12.2 \mathrm{~mm}$ (MNHNIU-2016-9655).
ETYMOLOGY. From the Latin, hastatus, spear-shaped, in reference to the long chelipeds of the species.

DESCRIPTION. Carapace: 1.2 times longer than broad, with some secondary striae and scales between main transverse ridges; dorsal surface moderately convex. Dorsal ridges with dense short non-iridescent setae and a few scattered long iridescent setae. Gastric region with 6 pairs of epigastric spines, longest pair behind supraocular spines, one pair between largest pair of spines. Two minute hepatic spines near margin, one parahepatic, one branchial dorsal on each side and one postcervical spine on left side. Frontal margins transverse. Lateral margins subparallel. First lateral spine at anterolateral angle, long, exceeding level of sinus between rostrum and supraocular spines; one small spine in front of anterior branch of cervical groove; end of anterior branch of cervical groove with tuft of iridescent setae. Branchial margins slightly convex, with five spines. Rostrum spiniform, about 0.6 times length of remaining carapace, slightly upwards directed, dorsally carinate. Supraocular spines reaching midlength of rostrum and end of corneae, slightly divergent, directed slightly upwards. Grooves between rostrum and supraocular spines shallow. Pterygostomian flap unarmed and not visible in dorsal view, ending in one spine. Epistome with ridge arising from marginal ridge of mouth, laterally leading to level of antennal gland aperture.

Sternum: 0.8 times longer than broad; maximum width at sternite 7 . Lateral parts of posterior sternites never with carinae or granules. Surface of thoracic sternites 4-5 with scales. Sternite 33.5 times wider than long, as wide as anterior margin of sternite 4 . Sternite 4 trapezoidal, anterior margin wide and contiguous to sternite 3 along entire length; 3.1 times wider than long, and 2.5 times wider than sternite 3 .

Abdomen: Anterior ridge of somite 2 with 1-2 small lateral spines on each side; somites 2-4 each with 5-7 uninterrupted or scale-like transverse ridges on tergite behind anterior ridge; some iridescent setae on each side of anterior ridges of somites 2-3; posteromedian margin of somite 6 straight. Posterior plates of telson moderately wide, each plate with length-breadth ratio 0.7 .

Eyes: Ocular peduncles as long as broad. Corneae dilated, maximum diameter 0.4 distance between bases of anterolateral spines.

Antennule: Article 1 (distal spines excluded) very long, about 0.3 times carapace length, 2.2 times longer than wide (excluding spines), slightly overreaching end of cornea, with 2 subequal distal spines; 2 spines on lateral margin, proximal one short, located at midlength of segment, distal one long, reaching end of distal spines.

Antenna: Article 1 not fused with cephalothorax, with strong distomesial spine reaching distal margin of article 4 . Article 2 with distomesial spine exceeding antennal peduncle, additional small spine along mesial margin; distolateral spine slightly reaching end of article 4 . Article 3 and 4 unarmed.

Mxp3: Ischium with strong distal spine on flexor margin. Merus shorter than ischium; flexor margin with 2 spines, proximal stronger than distal; extensor margin with small distal spine. Carpus unarmed.

P1: Long, 7.0 times carapace length, covered with scales, dense short plumose setae on each scale. Merus 2.5 length of carapace, 1.8 times as long as carpus, with some dorsal and mesial spines; distal spines short. Carpus 0.7 length of palm, 5.5 times as long as broad, with a few small spines along mesial and dorsal sides. Palm 5.5 times longer than broad, with some minute dorsal spines. Fingers 0.6 palm length; $1-$ 2 small marginal spines on each fingers. 


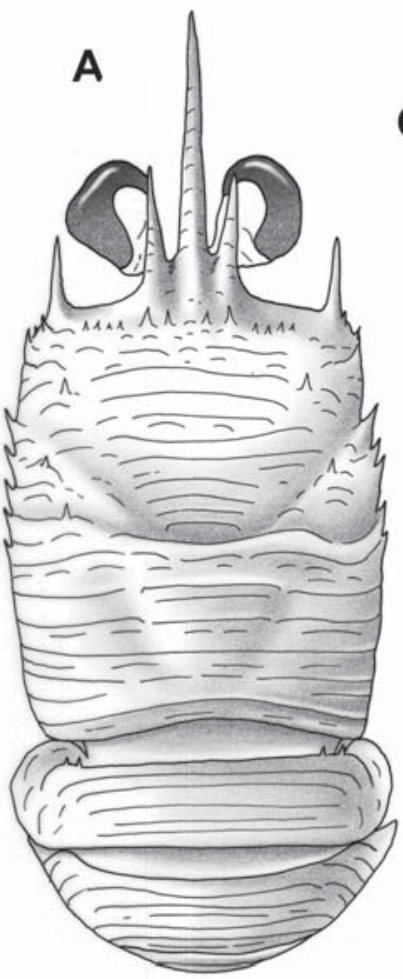

C
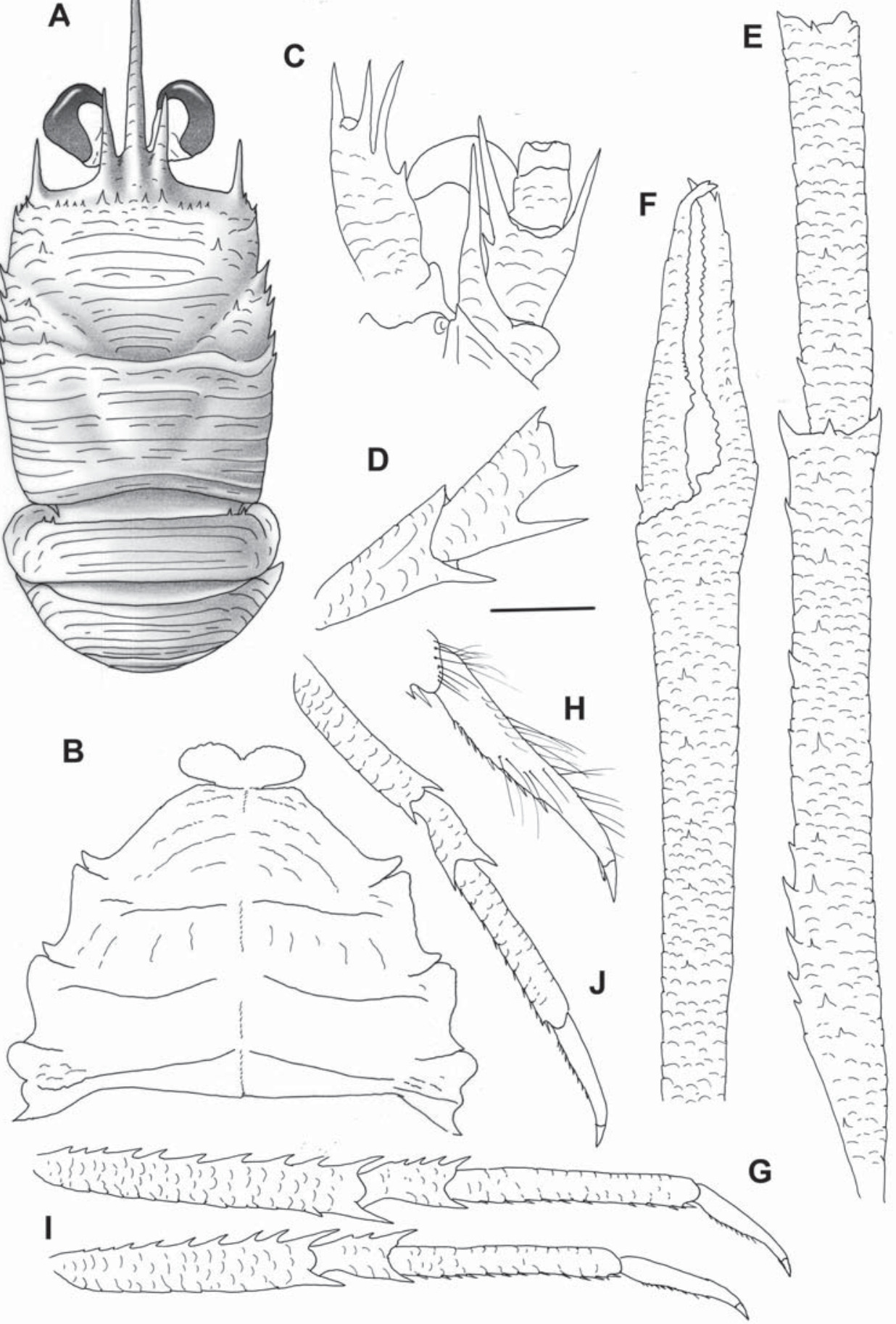

Fig. 1. Munida hastata sp.n., O7, $12.2 \mathrm{~mm}$ (MNHN-IU-2016-9655): A — carapace and pleon, dorsal; B — sternal plastron; C cephalic region, showing left antennular and antennal peduncles, ventral; D - right Mxp3, lateral; E - right P1, merus and carpus, lateral.; F — right P1, propodus and dactylus, lateral; $\mathrm{G}$ - right P2, lateral; $\mathrm{H}$ - right P2 dactylus, lateral; I — right P3, lateral; J - right P4, lateral. Scale: A, E, F, G, I, J - $4.0 \mathrm{~mm}$; B, C, D, H $-2.0 \mathrm{~mm}$.

Pис. 1. Munida hastata sp.n., ơ, 12,2 мм (MNHN-IU-2016-9655): А — карапакс и плеон, дорсально; В — стернальный пластрон; С - головная область, показаны левые левые антеннуальные и антеннальные стебельки, вентрально; D - правый Mхр3, латерально; E - правый P1, мерус и карпус, латерально.; F — правый P1, проподус и дактилус, латерально; G — правый P2, латерально; Н - правый Р2 дактилус, латерально; I — правый Р3, латерально; J — правый P4, латерально. Масштаб: А, Е, F, G, I, J - 4,0 мм; B, C, D, H-2,0 мм. 
P2-4: Moderately long and slender, with numerous long plumose setae and some long iridescent setae along extensor margin of articles. P2 2.5 times carapace length. Meri shorter posteriorly ( $\mathrm{P} 3$ merus 0.8 length of $\mathrm{P} 2$ merus, $\mathrm{P} 4$ merus 0.7 length of $\mathrm{P} 3$ merus). P2 merus thicker than those of $\mathrm{P} 3$ and P4; P2 merus 1.1 length of carapace, 7 times as long as broad, 1.4 times longer than P2 propodus; P3 merus 6 times longer than broad, 1.2 times longer than $\mathrm{P} 3$ propodus; P4 merus 4 times as long as broad, 1.1 times length of P4 propodus. Extensor margins of P2-3 meri with row of 9-10 proximally diminishing spines, and one distal spine on $\mathrm{P} 4$; flexor margins distally with $1-2$ spines followed proximally by several eminences; lateral sides unarmed. Carpi with 3-5 spines on extensor margin of $\mathrm{P} 2-3$, one distal spine on $\mathrm{P} 4$ lateral surface with several granules sub-paralleling extensor margin on $\mathrm{P} 2-4$; flexor margin with distal spine. Propodi 6.5-6.8 (P2-3), 5.1 (P4) times as long as broad; extensor margin unarmed; flexor margin with 10-11 slender movable spines on P2-4, distal end with one fixed spine. Dactyli slender, length $0.5-0.7$ that of propodi; flexor margin with 9-10 movable spinules, with spinule at base of unguis, wide unarmed gap between penultimate and ultimate spine; P2 dactylus 7.0 times longer than wide. P4 moderately long and slender, merocarpal articulation reaching anterior branchial margin of carapace.

GENETIC DATA. COI, 16S.

REMARKS. Munida hastata belongs to the group of species having five spines on the branchial lateral margins of the carapace, thoracic sternites without granules or carinae, anterior ridge of the second abdominal somite with 1-2 small spines on each side, article 1 of antennule with subequal distal spines, extensor margin of Mxp3 merus with small distal spine and terminal third of flexor margin of P24 dactyli unarmed between ultimate and penultimate spines. The new species is closely related to M. aurantiaca Macpherson, Rodríguez-Flores et Machordom, 2020, from PapuaNew Guinea [Macpherson et al., 2020]. Both species are morphologically very similar and only differ by the length and shape of P1: P1 are longer in males of the new species (7.0 times longer than carapace) than in M. aurantiaca (3.5 times); the carpus is 2.2 times longer than wide in M. aurantiaca, whereas it is 5.5 times in M. hastata.

Genetically both species are different. Munida hastata showed high divergence values with $M$. aurantiaca $(4.7 \%$ COI, $2.0 \% 16 \mathrm{~S}$ ).

DISTRIBUTION. Indonesia, Kei islands, between 212 and $221 \mathrm{~m}$.

\section{Munida vassilyi sp.n.}

Fig. 2.

HOLOTYPE. Indonesia, Kei islands. KARUBAR, Stn CP06, 22/10/1991, $05^{\circ} 49^{\prime} \mathrm{S}, 132^{\circ} 21^{\prime} \mathrm{E}, 287-298 \mathrm{~m}$ : M $10.3 \mathrm{~mm}$ (MNHNIU-2016-9654).

ETYMOLOGY. The species is named for our friend and colleague, the late Vassily Spiridonov, for his important contributions to carcinology.

DESCRIPTION. Carapace: As long as broad, with some secondary striae and scales between main transverse ridges, dorsal surface moderately convex. Dorsal ridges with dense short plumose setae, non-iridescent, and a few scattered long iridescent setae. Gastric region with 4-5 epigastric spines on either side, dorsal carapace surface otherwise unarmed. Frontal margins transverse. Lateral margins subparallel and slightly convex. First lateral spine at anterolateral angle, long, reaching level of sinus between rostrum and supraocular spines; two small spines in front of anterior branch of cervical groove; end of anterior branch of cervical groove with tuft of iridescent setae. Branchial margins with five spines. Rostrum spiniform, about 0.7 times length of remaining carapace, slightly upwards directed, dorsally not carinate. Supraocular spines not reaching midlength of rostrum and end of corneae, slightly divergent, directed slightly upwards. Grooves between rostrum and supraocular spines shallow. Pterygostomian region not visible in dorsal view, unarmed, ending in blunt angle. Epistome with ridge arising from marginal ridge of mouth, laterally leading to level of antennal gland aperture.

Sternum: 0.8 times longer than broad; maximum width at sternite 7. Surface of thoracic sternites 4-6 with numerous scales. Sternite 32.8 times wider than long, slightly wider than anterior margin of sternite 4 . Sternite 4 trapezoidal, anterior margin wide and subparallel to sternite 3 along entire border; 2.5 times wider than long, and 2.5 times wider than sternite 3 . Lateral parts of posterior sternites without carinae or granules.

Abdomen: Anterior ridge of somites unarmed; somites 2-4 each with 7-9 uninterrupted or scale-like transverse ridges on tergite behind anterior ridge; some iridescent setae on each side of anterior ridges of somites; posteromedian margin of somite 6 straight. Posterior plates of telson moderately wide, each plate with length-breadth ratio 0.7 .

Eyes: Ocular peduncles as long as broad. Corneae dilated, maximum diameter 0.5 distance between bases of anterolateral spines.

Antennule: Article 1 (distal spines excluded) very long, about 0.3 times carapace length, twice longer than wide (excluding spines), slightly exceeding end of corneae, with 2 distal spines, distomesial slightly longer than distolateral; 2 spines on lateral margin, proximal one short, located at midlength of segment, distal one long, nearly reaching end of distolateral spine.

Antenna: Article 1 not fused with cephalothorax, with distomesial spine nearly reaching distal margin of article 2 . Article 2 with distomesial spine exceeding antennal peduncle, additional small spine along mesial margin; distolateral spine slightly reaching end of article 3 . Article 3 and 4 unarmed.

Mxp3: Ischium with strong distal spine on flexor margin. Merus shorter than ischium; flexor margin with 2 spines, proximal stronger than distal; extensor margin with small distal spine. Carpus unarmed.

P1: 4.0 times carapace length, covered with scales, dense short plumose setae on each scale, and some scattered long spines. Merus 1.3 length of carapace, 1.8 times as long as carpus, with some dorsal and mesial spines; distomesial spine strong, not reaching first quarter of carpus. Carpus 0.8 length of palm, 2.3 times as long as broad, with a few small spines along mesial and dorsal sides. Palm 2.5 times longer than broad, with some minute dorsal spines; row of small spines along mesial and lateral margins. Fingers as long as palm; movable and fixed fingers with proximal and distal spines.

P2-4: Moderately long and slender, covered with setose scales, with numerous long plumose setae and some long iridescent setae along extensor margin of articles. P2 2.3 times carapace length. Meri shorter posteriorly (P3 merus 0.8 length of $\mathrm{P} 2$ merus, $\mathrm{P} 4$ merus 0.7 length of $\mathrm{P} 3$ merus); P2 merus thicker than those of P3 and P4. P2 merus 0.9 length of carapace, 5.5 times as long as broad, 1.5 times 


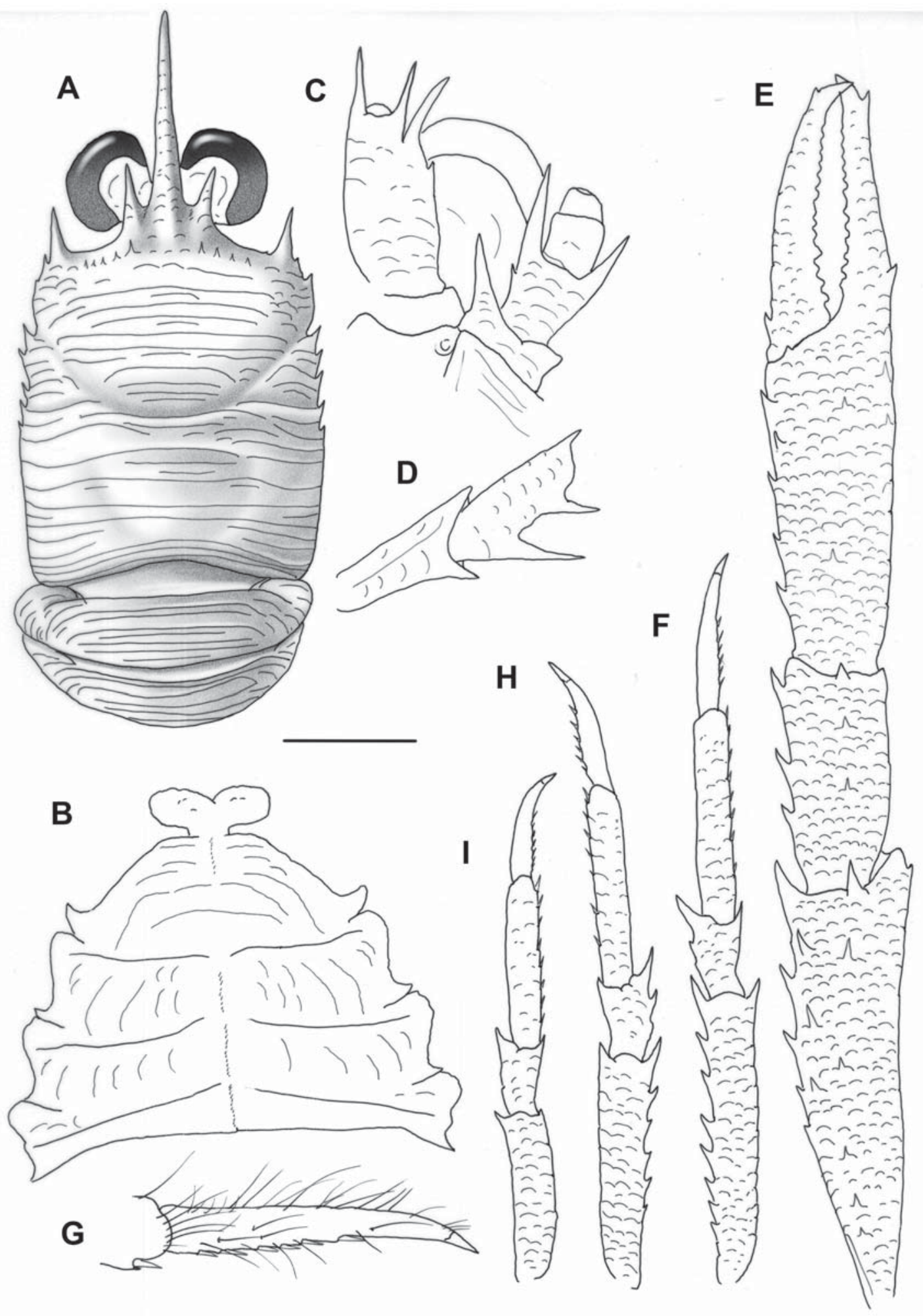

Fig. 2. Munida vassilyi sp.n., O', $10.3 \mathrm{~mm}$ (MNHN-IU-2016-9654): A — carapace and pleon, dorsal; B — sternal plastron; C cephalic region, showing left antennular and antennal peduncles, ventral; D - right Mxp3, lateral; E - right P1, lateral; F — right P2, lateral; G — right P2 dactylus, lateral; H - left P3, lateral; I - right P4, lateral. Scale: A, E, F, H, I - 4.0 mm; B, C, D, G - 2.0 mm.

Рис. 2. Munida vassilyi sp.n., О7, 10,3 мм (MNHN-IU-2016-9654): А - карапакс и плеон, дорсально; В - стернальный пластрон; С — головная область, показаны левый антеннуальный и антеннальный стебельки, вентрально; D — правый Мхр3, латерально; Е - правый P1, латерально; F — правый Р2, латерально; G - правый Р2 дактилус, латерально; Н - левый Р3, латерально; I — правый Р4, латерально. Масштаб: А, Е, F, Н, I — 4,0 мм; В, С, D, G - 2,.0 мм. 
longer than P2 propodus; P3 merus 4.5 times longer than broad, 1.3 times longer than P3 propodus; P4 merus 3.8 times as long as broad, 1.1 times length of $\mathrm{P} 4$ propodus. Extensor margins of $\mathrm{P} 2-3$ meri with row of $7-8$ proximally diminishing spines, one distal spine on P4; flexor margins distally with 1-2 spines followed proximally by several eminences; lateral sides unarmed. Carpi with 3 spines on extensor margin of $\mathrm{P} 2-3$, one distal spine on $\mathrm{P} 4$; lateral surface with several granules sub-paralleling extensor margin on P2-4; flexor margin with distal spine. Propodi 5.0-5.5 (P23), 4.7 (P4) times as long as broad; extensor margin unarmed; flexor margin with 7-8 slender movable spines on P2-4, distal end with one fixed spine. Dactyli slender, length $0.7-0.8$ that of propodi; flexor margin with 6-7 movable spinules, without spinule at base of unguis, distal third unarmed; P2 dactylus 7.0 times longer than wide. P4 moderately long and slender, merocarpal articulation reaching anterior branchial margin of carapace.

GENETIC DATA. COI, $16 \mathrm{~S}$

REMARKS. Munida vassilyi belongs to the group of species having five spines on the branchial lateral margins of the carapace, dorsal surface of the carapace with epigastric spines only, thoracic sternites without granules or carinae, anterior ridge of the abdominal somites unarmed, extensor margin of Mxp3 merus with small distal spine and terminal third of flexor margin of P2 4 dactyli unarmed. The new species is closely related to M. runcinata Macpherson, 1994, from New Caledonia, Vanuatu, Wallis and Futuna, Fiji and Tonga [Macpherson, 1994]. However, both species can be distinguished by the following characters:

Thoracic sternites with numerous scales in the new species, whereas the sternites are smooth and there are only a few scales in the sternite 4 in M. runcinata.

The antennular article 1 has the distomesial spine slightly longer than the distolateral in M. vassilyi, whereas they are subequal in $M$. runcinata.

The distomesial spine of the antennal article 1 clearly exceeds the article 2 in $M$. runcinata, whereas this spine nearly reaches the distal margin of this article in the new species.

Genetically both species are different. Munida vassilyi showed high divergence values with $M$. runcinata $(5.9 \%$ COI, no data of $16 \mathrm{~S}$ for $M$. runcinata)

DISTRIBUTION. Indonesia, Kei islands, between 287 and $298 \mathrm{~m}$.

Acknowledgements. We thank to our colleagues who made material available for this study: A. Crosnier, B. Richer de Forges, R. Cleva, P. Bouchet, L. Corbari, and P. Martin- Lefèvre from the Muséum national d'Histoire naturelle, Paris. We thank K. Baba from Kumamoto University for his enormous support and suggestions and K. Schnabel from NIWA for her review of the manuscript. We also thank R. García and G. Carreras for their help with the lab work. The study was partially supported by the GALETTE project (Galatheoidea lobster adaptations to deep sea environments), co-funded by the CNRS (France) and the CSIC (Spain) (2018FR0053)

\section{References}

Ahyong S.T., Baba K., Macpherson E., Poore G.C.B. 2010. A new classification of the Galatheoidea (Crustacea: Decapoda: Anomura) // Zootaxa. Vol.2676. P.57-68.
Baba K. 1977. Biological results of the Snellius Expedition XXVIII. The galatheid Crustacea of the Snellius Expedition // Zoologische Mededelingen, Leiden. Vol.50. P243-259.

Baba K. 1988. Chirostylid and galatheid crustaceans (Decapoda: Anomura) of the "Albatross" Philippine Expedition, 19071910 // Researches on Crustacea. Special Number 2 P.1-203.

Baba K. 2018. Chirostylidae of the Western and Central Pacific: Uroptychys and a new genus (Crustacea: Decapoda: Anomura) // Tropical Deep-Sea Benthos, volume 30. Mémoires du Muséum national d'Histoire naturelle, Paris. Vol.212. P.1612 .

Baba K., de Saint Laurent M. 1996. Crustacea Decapoda: Revision of the genus Bathymunida Balss, 1914, and description of six new related genera (Galatheidae) // Crosnier A. (ed.). Résultats des Campagnes MUSORSTOM. Vol.15. Mémoires du Muséum National d'Histoire Naturelle, Paris. Vol.168. P.433-502.

Baba K., Macpherson E. 1991. Reexamination of the type material of Munida militaris Henderson, 1885 (Crustacea: Decapoda: Galatheidae), with the selection of a lectotype // Proceedings of the Biological Society of Washington. Vol.104. P.538-544.

Baba K., Macpherson E., Lin C.W., Chan T.Y. 2009. Crustacean Fauna of Taiwan. Squat lobsters (Chirostylidae and Galatheidae). Keelung: National Taiwan Ocean University. 312 pp.

Baba K., Macpherson E., Poore G.C.B., Ahyong S.T., Bermudez A., Cabezas P., Lin C.W., Nizinski M., Rodrigues C., Schnabel K.E. 2008. Catalogue of squat lobsters of the world (Crustacea: Decapoda: Anomura - families Chirostylidae, Galatheidae and Kiwaidae) // Zootaxa. Vol.1905. P.1-220.

Folmer O., Black M., Hoeh W., Lutz R., Vrijenhoek R. 1994. DNA primers for amplification of mitochondrial cytochrome c oxidase subunit I from diverse metazoan invertebrates // Molecular Marine Biology and Biotechnology. Vol.3. P.294-299.

Gordon I. 1930. On the species of the galatheid genus, Eumunida (Crustacea, Decapoda) // Proceedings of the General Meetings for Scientific Business of the Zoological Society of London. Vol.1929. P741-753.

Henderson J.R. 1888. Report on the Anomura collected by H.M.S. Challenger during the years 1873-76// Report on the Scientific Results of the Voyage of H.M.S. Challenger during the years 1873-76. Zoology. Vol.27. P1-221.

Katoh K., Misawa K., Kuma K.I., Miyata T. 2002. MAFFT: a novel method for rapid multiple sequence alignment based on fast Fourier transform // Nucleic Acids Research. Vol.30. P.30593066.

Leach W.E. 1820. Galatéadées // Dictionnaire des Sciences Naturelles. Paris: F.G. Levreault. P.49-56.

Machordom A., Araujo R., Erpenbeck D., Ramos M.A. 2003. Phylogeography and conservation genetics of endangered European Margaritiferidae (Bivalvia: Unionoidea) // Biological Journal of the Linnean Society. Vol.78. P.235-252.

Macpherson E. 1993. Crustacea Decapoda: species of the genus Munida Leach, 1820 (Galatheidae) collected during the MUSORSTOM and CORINDON cruises in the Philippines and Indonesia // Crosnier A. (ed.). Résultats des Campagnes MUSORSTOM. Vol.10. Mémoires du Muséum National d'Histoire Naturelle, Paris. Vol.156. P.421-442.

Macpherson E. 1994. Crustacea Decapoda: Studies on the genus Munida Leach, 1820 (Galatheidae) in New Caledonia and adjacent waters with descriptions of 56 new species // Crosnier A. (ed.). Résultats des Campagnes MUSORSTOM. Vol.12. Mémoires du Muséum National d'Histoire Naturelle, Paris. Vol.161. P.421-569.

Macpherson E. 1997. Crustacea Decapoda: species of the genera Agononida Baba \& de Saint Laurent, 1996 and Munida Leach, 1820 (Galatheidae) from the KARUBAR cruise // Crosnier A., Bouchet P. (eds.). Résultats des Campagnes MUSORSTOM. Vol.16. Mémoires du Muséum National d'Histoire Naturelle, Paris. Vol.172. P.597-612.

Macpherson E., Baba K. 1993. Crustacea Decapoda: Munida japonica Stimpson, 1858, and related species (Galatheidae) // Crosnier A. (ed.). Résultats des Campagnes MUSORSTOM. Vol.10. Mémoires du Muséum National d'Histoire Naturelle, Paris. Vol.156. P.381-420 
Macpherson E., Baba K. 2011. Chapter 2. Taxonomy of squat lobsters // Poore G.C.B., Ahyong S.T., Taylor J. (eds.). The biology of squat lobsters. Melbourne: CSIRO Publishing, and Boca Raton: CRC Press. P.39-71.

Macpherson E., Richer de Forges B., Schnabel K., Samadi S., Boiselier M.C., Garcia-Rubies A. 2010. Biogeography of the deep-sea galatheid squat lobsters of the Pacific Ocean // Deepsea Research I. Vol.57. P.228-238.

Macpherson E., Rodríguez-Flores P.C., Machordom A. 2020. Squat lobsters of the families Munididae and Munidopsidae from Papua New Guinea // Ahyong S.T., Chan T.-Y., Corbari L. (eds.). Tropical Deep-Sea Benthos. Vol.31. Mémoires du Muséum national d'Histoire naturelle, Paris. Vol.213. P.11-120.

Man de J.G. 1888. Bericht über die von Herrn Dr. J. Brock im indischen Archipel gesammelten Decapoden und Stomatopoden // Archiv für Naturgeschichte. Bd.53. S.215-600.

Man de J.G. 1902. Die von Herrn Professor Kükenthal im Indischen Archipel gesammelten Dekapoden und Stomatopoden // Abhandlungen der Senckenbergischen Naturforschenden Gesellschaft. Bd.25. S.467-929.

Ortmann A.E. 1894. Crustaceen // Semon R. (Hrsg.). Zoologische Forschungsreisen in Australien und dem malayischen Archipe // Denkschriften der Medicinisch-Naturwissenschaftlichen Gesellschaft zu Jena. Bd.8. S.3-80.

Palumbi S.R., Martin A., Romano S., McMillan W.O., Stice L., Grabowski G. 2002. The simple fool's guide to PCR. University of Hawaii, Honolulu.

Rodríguez-Flores P.C., Macpherson E., Machordom A. 2019. Revision of the squat lobsters of the genus Leiogalathea Baba, 1969 (Crustacea, Decapoda, Munidopsidae) with the description of 15 new species // Zootaxa. Vol.4560. P.201-256.
Rodríguez-Flores P.C., Macpherson E., Machordom A. 2021. Revision of the squat lobsters of the genus Phylladiorhynchus Baba, 1969 (Crustacea, Decapoda, Galatheidae) with the description of 41 new species // Zootaxa (in press).

Saint Laurent M. de, Poupin J. 1996. Crustacea, Anomura: Les espèces indo-ouest pacifiques du genre Eumunida Smith, 1880 (Chirostylidae) Description de six espèces nouvelles // Crosnier A. (ed.). Résultats des Campagnes MUSORSTOM. Vol.15. Mémoires du Museum National d'Histoire Naturelle, Paris. Vol.168. P.337-385.

Samouelle G. 1819. The entomologists' useful compendium; or an introduction to the knowledge of British Insects, comprising the best means of obtaining and preserving them, and a description of the apparatus generally used; together with the genera of Linné, and modern methods of arranging the Classes Crustacea, Myriapoda, spiders, mites and insects, from their affinities and structure, according to the views of Dr. Leach. Also an explanation of the terms used in entomology; a calendar of the times of appearance and usual situations of near 3,000 species of British Insects; with instructions for collecting and fitting up objects for the microscope. London: Thomas Boys. 496 pp., 412 pls.

Schnabel K.E., Cabezas P., McCallum A., Macpherson E., Ahyong S.T., Baba K. 2011. Chapter 5. World-wide distribution patterns of squat lobsters // Poore G.C.B., Ahyong S.T., Taylor J. (eds.). The biology of squat lobsters. Melbourne: CSIRO Publishing, and Boca Raton: CRC Press. P.149-182.

Swofford D.L. 2002. PAUP: phylogenetic analysis using parsimony. Version 4.0. b10. 